\title{
Identification and Pathogenicity of Chrysoporthe cubensis on Eucalyptus and Syzygium spp. in South China
}

\author{
S. F. Chen, Department of Microbiology and Plant Pathology, Forestry and Agricultural Biotechnology Institute \\ (FABI), University of Pretoria, Pretoria, South Africa, and China Eucalypt Research Centre (CERC), Chinese \\ Academy of Forestry (CAF), China; M. Gryzenhout and J. Roux, Department of Microbiology and Plant Pathol- \\ ogy, FABI; Y. J. Xie, CERC, CAF; M. J. Wingfield, Department of Microbiology and Plant Pathology, FABI; and \\ X. D. Zhou, FABI; CERC, CAF
}

\begin{abstract}
Chen, S. F., Gryzenhout, M., Roux, J., Xie, Y. J., Wingfield, M. J., and Zhou, X. D. 2010. Identification and pathogenicity of Chrysoporthe cubensis on Eucalyptus and Syzygium spp. in South China. Plant Dis. 94:1143-1150.

The genus Chrysoporthe includes important pathogens of plantation-grown Eucalyptus spp. and has been reported from several tree genera in the order Myrtales in tropical and subtropical areas of the world. During disease surveys in South China, fruiting structures typical of Chrysoporthe spp. were observed on cankers on Eucalyptus spp. and Syzygium cumini trees. The aim of this study was to confirm the identity of the Chrysoporthe cubensis infecting the Eucalyptus spp. and $S$. cumini and to test the pathogenicity of the fungus. Following glasshouse trials to select virulent isolates, field inoculations were undertaken to screen different commercial Eucalyptus genotypes for their susceptibility to the fungus. Isolates were characterized based on their morphology and DNA sequence data for the $\beta$-tubulin and internal transcribed spacer regions of the ribosomal DNA. Results showed that the putative pathogen represented the Asian form of $C$. cubensis, which occurred on numerous different Eucalyptus spp. and hybrid clones as well as $S$. cumini. Field inoculations showed that all six of the Eucalyptus genotypes tested are susceptible to infection by $C$. cubensis. Significant differences were observed between them, providing prospects to select disease-tolerant planting stock in the future.
\end{abstract}

Stem canker diseases caused by Chrysoporthe spp. are considered among the most important diseases of plantationgrown Eucalyptus spp. in the tropics and subtropics $(12,38)$. Infection of susceptible young trees can lead to rapid tree death while cankers weaken the stems of older trees, often resulting in stem breakage $(4,24,38,40)$. The stem canker diseases caused by Chrysoporthe spp. have had a substantial impact on the development of Eucalyptus forestry in the tropics and Southern Hemisphere $(1,2,24,35,38)$; vegetative propagation of these trees emerged from efforts to avoid the disease using resistant hybrid clones (38).

It is well established that Chrysoporthe canker, previously known as Cryphonectria canker, of Eucalyptus spp. that once was thought to be caused by a single fungus, Cryphonectria cubensis (Bruner) Gryzenh. \& M.J. Wingf., is caused by a number of different species of Chrysoporthe in different parts of the world (9). These include

Corresponding author: X. Zhou

E-mail: cerc.zhou@gmail.com

orxu.zhou@fabi.up.ac.za

Accepted for publication 28 May 2010.

doi:10.1094/PDIS-94-9-1143

(C) 2010 The American Phytopathological Society
Chrysoporthe cubensis, with a wide distribution and representing two distinct phylogenetic lineages, one in South and Central America and a second in Southeast Asia (12). Other species of Chrysoporthe on Eucalyptus spp. are C. austroafricana Gryzenh. \& M.J. Wingf. in Southern Africa (9), C. doradensis Gryzenh. \& M.J. Wingf. in Ecuador (10), and C. zambiensis Chungu, Gryzenh. \& Jol. Roux in Zambia (3).

Apart from Eucalyptus spp., Chrysoporthe spp. have been shown to be especially prevalent on other tree species in the order Myrtales (12). These fungi have been found on Syzygium spp. (Myrtaceae) in Africa $(13,22,23)$, Brazil (14), Indonesia (14,20), and Malaysia (25); on Tibouchina spp. (Melastomataceae) in South Africa (18), South America (11,29,39), and Southeast Asia (11); and on Lagerstroemia indica (Lythraceae) in Cuba (11). C. cubensis is also known from other trees in the family Melastomataceae, including Miconia spp., Rhynchanthera mexicana, and Clidemia sericea in Central and South America $(11,26)$ and Melastoma melabathricum in Indonesia (11).

Chrysoporthe cubensis has been reported from different hosts in several regions of Southeast Asia. These reports include those from Eucalyptus spp. in India (30), Indonesia (24), Malaysia (24),
Thailand (21), Vietnam (24), and Hong Kong, China $(14,21,30)$. The fungus has also been reported from native Syzygium aromaticum in Sulawesi, Indonesia $(14,20)$; from native $M$. melabathricum (Melastomataceae) in Sumatra, Indonesia (11); and on non-native Tibouchina urvilleana (Melastomataceae) in Singapore and Thailand (11).

During the course of the past two decades, China has invested significantly in the establishment of plantations of Eucalyptus spp. as a source of pulp for the manufacture of paper, particle board, and plywood, as well as timber for construction. Approximately two million hectares of Eucalyptus plantations have already been established in South China (41) Similar to the situation in other countries, these trees have rapidly been affected by diseases (42). Recent surveys of Eucalyptus plantations in South China identified several pathogens affecting these trees, including $C$. cubensis associated with a stem canker disease (42). Early work in the country was conducted based only on fungal morphology, and there was no extensive survey of the species diversity, host range of the fungus, or consideration of its pathogenicity. The aim of this study was to survey Eucalyptus and related species for the presence of Chrysoporthe spp. and to identify these fungi based on DNA sequence data and morphological characters. In addition, the relative susceptibility of commercially planted Eucalyptus genotypes to Chrysoporthe canker was evaluated in field inoculation trials.

\section{MATERIALS AND METHODS}

Sampling. Eucalyptus plantations in three provinces in South China (Fig. 1), where most plantations of these trees have been established, were surveyed for the presence of stem cankers in November and December 2006 and June 2007 as well as between September and November 2008. Where present in these areas, S. cumini trees that are related to Eucalyptus spp. in the family Myrtaceae were also examined for the presence of stem cankers. Sections of bark from the surface of stem cankers bearing fruiting structures resembling Chrysoporthe spp., including ascostromata and conidiomata, were collected and trans- 
ported to the laboratory for isolations. Samples were incubated in moist chambers for 1 to 3 days to induce the production of spores from the fruiting bodies. Single spore tendrils were transferred to $2 \%$ malt extract agar (MEA; $20 \mathrm{~g}$ of Biolab malt extract, $20 \mathrm{~g}$ of Biolab agar, and 1 liter water; Biolab, Merck, Midrand, South Africa) and incubated at $25^{\circ} \mathrm{C}$. From the resultant cultures, single hyphal tips were transferred to fresh $2 \%$ MEA to obtain pure cultures. All cultures are maintained in the culture collection (CMW) of the Forestry and Agricultural Biotechnology Institute (FABI), University of Pretoria, South Africa, and the China Eucalypt Research Centre (CERC), Chinese Academy of Forestry (CAF), China.

Morphology. To study the morphology of the fungi collected, fruiting structures were taken from bark specimens and sectioned using a Leica CM1100 cryostat (Setpoint Technologies) at $-20^{\circ} \mathrm{C}$ following the method described by Gryzenhout et al. (9). Samples from China were compared with those of Chrysoporthe spp. $(9,12)$. For measurements, structures from the bark on five trees of Eucalyptus clones W5 and U6, respectively, and 10 from $S$. cumini trees from GuangDong Province (Table 1; Fig. 1), were selected. Measurements were made from 25 conidiophores, basal cells of conidiophores, conidia, asci, and ascospores. The results are presented as minimum - (mean - standard deviation) - (mean + standard deviation $)-$ maximum. To obtain an indication of the minimum and maximum size ranges of the stromata, measurements were obtained from structures representing the smallest and largest for the anamorph and teleomorph stromata on both Eucalyptus and $S$. cumini trees.

DNA sequence comparisons. Representative isolates collected from different Eucalyptus species or clones and S. cumini in different geographic regions of South
China (Table 1; Fig. 1) were selected and used for DNA sequence comparisons. Prior to DNA extraction, isolates were grown in $2 \% \mathrm{MEA}$ at $25^{\circ} \mathrm{C}$ for 5 to 7 days. For each isolate, actively growing mycelium from one MEA plate per isolate was scraped from the surface of the media using a sterile scalpel and transferred to 1.5- $\mu$ l Eppendorf tubes. DNA was extracted from the mycelium following the method used by Myburg et al. (21). DNA was separated by electrophoresis on a $1 \%$ agarose gel, stained with ethidium bromide, and visualized under UV light. Samples were treated with $3 \mu$ of RNase (1 $\mathrm{mg} / \mathrm{ml}$ ) and left overnight at $37^{\circ} \mathrm{C}$ to degrade RNA.

The internal transcribed spacer (ITS) regions, including the $5.8 \mathrm{~S}$ ribosomal DNA operon and two regions within the $\beta$ tubulin gene region, were amplified using the primer pairs ITS1 and ITS4 (37) and $\beta \mathrm{t} 1 \mathrm{a} / \beta \mathrm{t} 1 \mathrm{~b}$ and $\beta \mathrm{t} 2 \mathrm{a} / \beta \mathrm{t} 2 \mathrm{~b}$, respectively (8). Polymerase chain reaction (PCR) conditions were as outlined by Myburg et al. (19). PCR products were visualized with UV light on $1 \%$ agarose (ethidium bromide-stained) gels. The amplified products were purified using 6\% Sephadex G-50 columns (Steinheim, Germany) as described by the manufacturers.

Each PCR product was sequenced in both directions with the same primers that were used for PCR reactions. The ABI PRISM Big Dye Terminator Cycle Sequencing Ready Reaction Kit (PerkinElmer Applied Biosystems, Foster City, CA) was used to perform the sequencing reactions. The sequence products were purified using 6\% Sephadex G-50 columns, whereafter electropherograms were generated on an ABI PRISM 3100 autosequencer (Perkin-Elmer Applied Biosystems). Nucleotide sequences were analyzed using MEGA4 (33). All sequences obtained in this study have been deposited in GenBank (Table 1).
Sequences were aligned with the online version of MAFFT v. 5.667 (16), using the iterative refinement method (FFT-NS-i settings), and adjusted manually. The sequence data were analyzed using phylogenetic analyses using phylogeny (PAUP; version 4.0b10) (32). The combinability of the ITS and $\beta$-tubulin 1 and 2 gene sequence data sets was determined with a partition homogeneity test (PHT) in PAUP $(6,32)$. Most parsimonious trees were obtained with heuristic searches using stepwise addition and tree bisection and reconstruction (TBR) as the branch-swapping algorithms. All equally parsimonious trees were saved and all branches equal to zero were collapsed. Gaps were treated as the fifth character. A bootstrap analysis (50\% majority rule, 1,000 replications) was done to determine the confidence levels of the tree-branching points (7). Previously published sequences for $C$. austroafricana, $C$. cubensis, C. doradensis, C. hodgesiana (Gryzenh. \& M.J. Wingf.) Gryzenh. \& M.J. Wingf., and C. inopina Gryzenh. \& M.J. Wingf. (3,9-11) were used for comparative purposes. Cryphonectria parasitica (Murrill) M.E. Barr (Cryphonectriaceae) was used as the outgroup taxon to root the phylogenetic trees (12).

Pathogenicity tests. Glasshouse trials. Six isolates (CMW26888, CMW26891, CMW26892, CMW26895, CMW26929, and CMW26932) from different locations and Eucalyptus genotypes in China (Table 1) were selected for inoculations. These isolates were inoculated into trees of a susceptible Eucalyptus grandis clone under glasshouse conditions. This was done to select the most virulent isolates for field inoculations. The trees were approximately $2 \mathrm{~m}$ tall and had diameters of approximately $10 \mathrm{~mm}$. Before inoculation, the trees were allowed to acclimatize to the glasshouse conditions of $25^{\circ} \mathrm{C}$ and $14 \mathrm{~h}$ of daylight with $10 \mathrm{~h}$ of darkness. Fungal isolates were grown at $25^{\circ} \mathrm{C}$ under con-
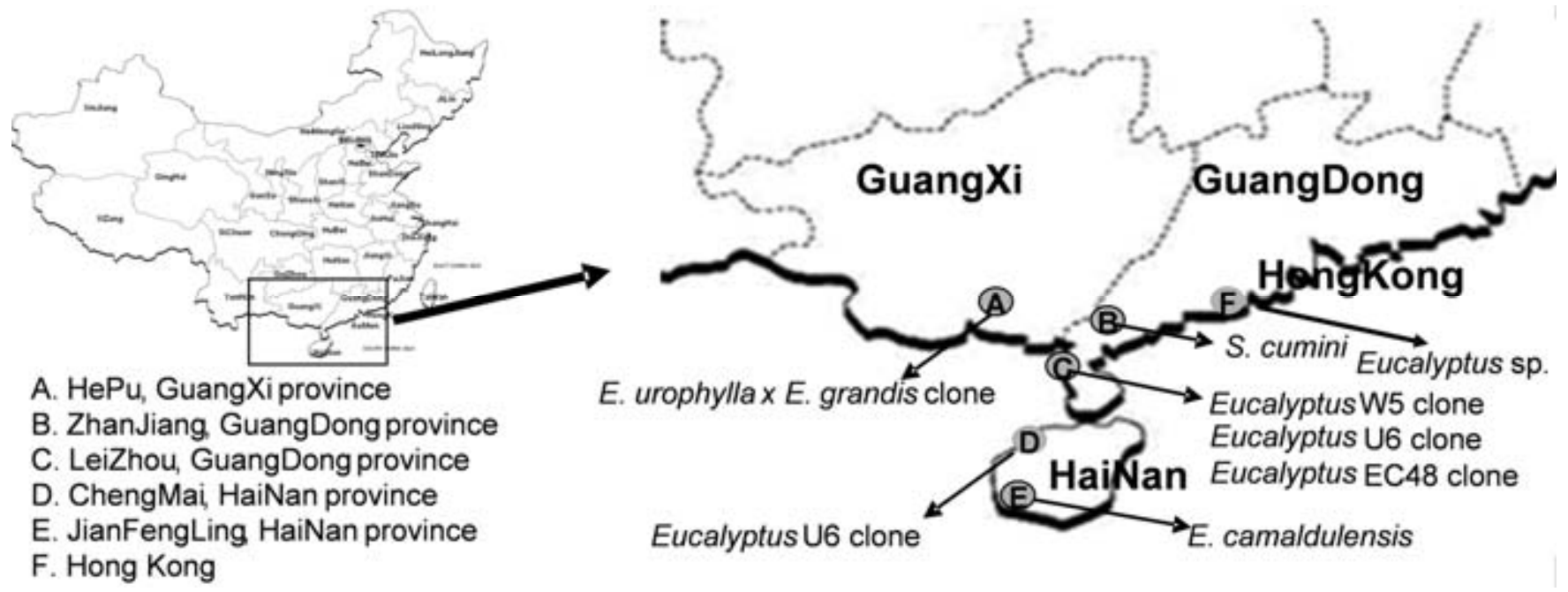

Fig. 1. Map of China indicating areas and species of Eucalyptus and Syzygium from which Chrysoporthe cubensis isolates were collected and identified. Records of C. cubensis on Eucalyptus spp. in Hong Kong are from previous studies $(15,21,30)$. 
tinuous fluorescent light for 6 days prior to inoculation.

In order to expose the cambium, wounds were made in the bark at a constant height (about $300 \mathrm{~mm}$ above the seedling medium) using a cork borer ( $7 \mathrm{~mm}$ in diameter). Discs of the same size from the actively growing colonies were inserted into the wounds with the mycelium facing the xylem. To prevent desiccation and contamination, wounds were covered with Parafilm (Pechiney Plastic Packing, Chicago). The six isolates were inoculated into the stems of 10 trees each. Ten trees were also inoculated with sterile MEA plugs to serve as controls. The 70 inoculated trees were arranged randomly in the glasshouse.
Trees were inoculated in April 2008 and results evaluated after 6 weeks by measuring the lengths of lesions in the cambium. Reisolations were made from the resultant lesions by plating small pieces of discolored xylem onto $2 \% \mathrm{MEA}$ at $25^{\circ} \mathrm{C}$. Reisolations were made from four randomly selected trees per isolate and from all trees inoculated as controls. Results were ana-

Table 1. Isolates used for phylogenetic analysis and pathogenicity trials in this study

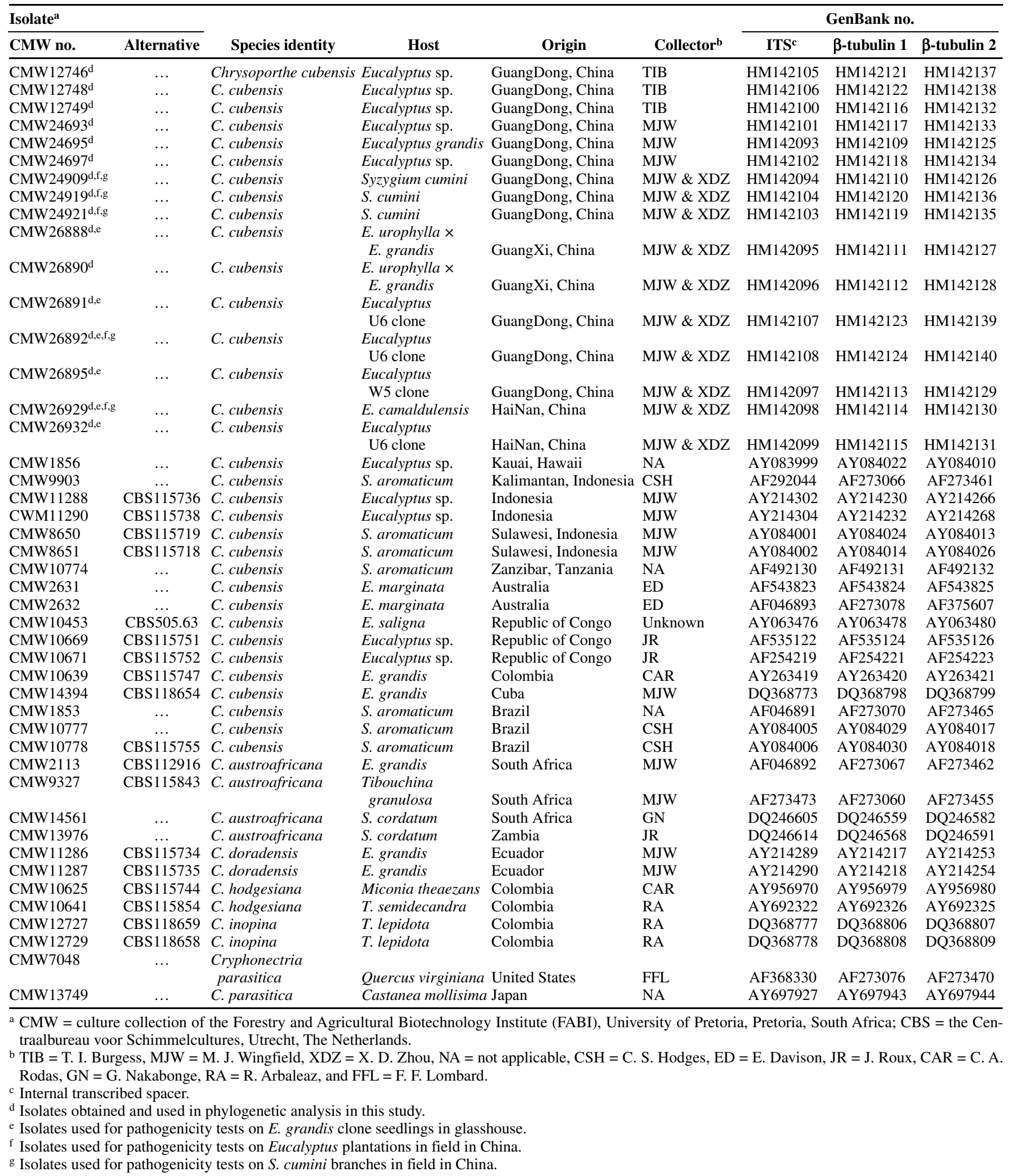


lyzed in SAS (version 8) using the PROC general linear model (GLM) (28). Analysis of variance (ANOVA) was used to determine the effects of fungal strain on lesion length. Prior to ANOVA, homogeneity of variance across treatments was verified. For significance tests among means, Fisher's protected test was used. $F$ values with $P<0.05$ were considered significant.

Field trials. To evaluate the relative susceptibility of commercially planted Eucalyptus spp. and clones grown in South
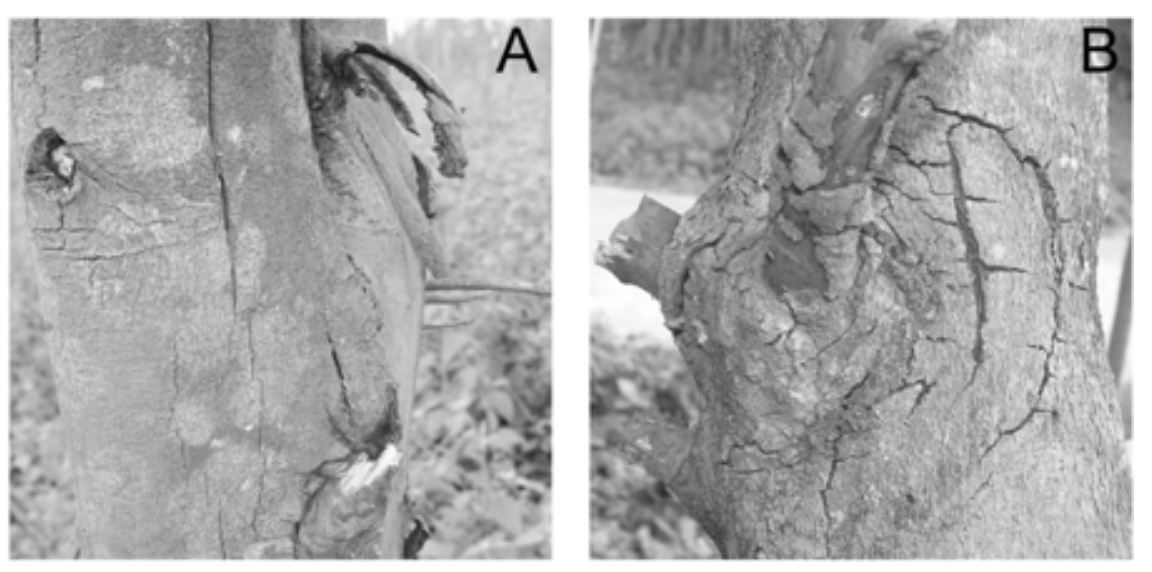

Fig. 2. Symptoms of infection by Chrysoporthe cubensis on A, Eucalyptus spp. and B, Syzygium cumini in China

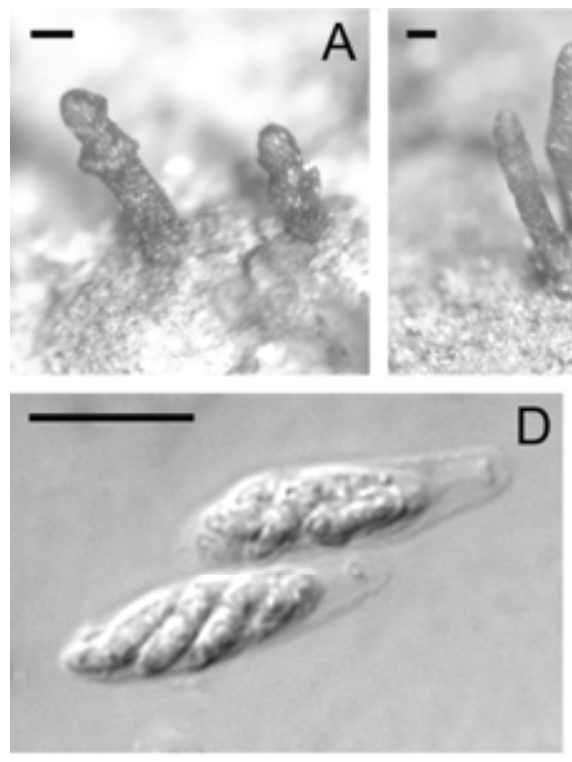

China, field inoculations were done using isolates (CMW26892 and CMW26929) identified in the glasshouse inoculations as most virulent. Three isolates (CMW24909, CMW24919, and CMW24921) originating from S. cumini (Table 1) were also used in the study. The field trial was situated in the ZhanJiang area of GuangDong Province and consisted of seven Eucalyptus genotypes, including pure species and hybrids. These included an E. grandis clone (CEPT-1), an E. grandis $\times$ E. tereticornis
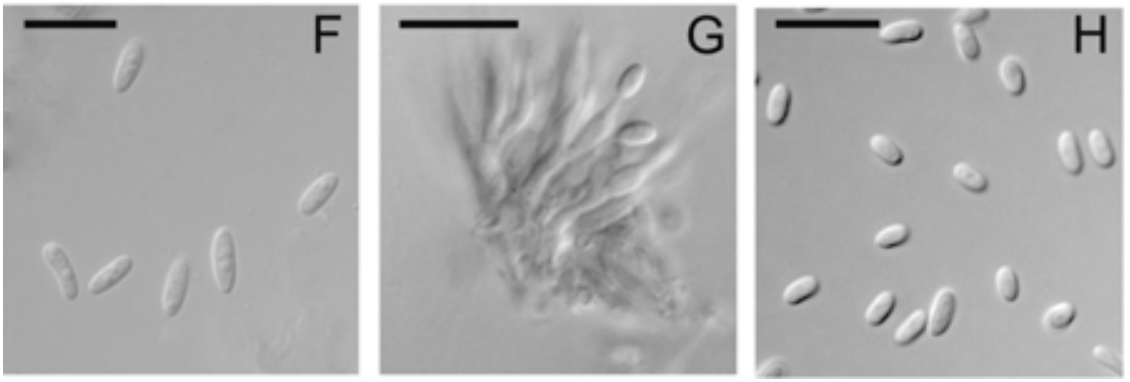

Fig. 3. Fruiting structures of Chrysoporthe cubensis from a Eucalyptus sp. and Syzygium cumini in China. A, Ascostroma on bark of Eucalyptus sp. B, Ascostroma on bark of S. cumini. C, Conidioma on bark of Eucalyptus sp. D, Asci from S. cumini tree. E, Ascospores from S. cumini bark. F, Ascospores from Eucalyptus sp. G, Conidiophores from Eucalyptus sp. H, Conidia from Eucalyptus sp. Bars: A, B, and C $=100 \mu \mathrm{m} ; \mathrm{D}, \mathrm{E}, \mathrm{F}, \mathrm{G}$, and $\mathrm{H}=10 \mu \mathrm{m}$. clone (CEPT-2), an E. pellita genotype (CEPT-3), two E. urophylla $\times$ E. grandis clones (CEPT-4 and CEPT-7), an E. urophylla clone (CEPT-5), and an E. wetarensis clone (CEPT-6). The isolates originating from $S$. cumini were inoculated onto two of the Eucalyptus genotypes (CEPT-6 and CEPT-7) due to limited availability of trees for inoculation. At the time of inoculation, trees were 1 year old and 6 to 10 trees of each genotype were inoculated per isolate. An equal number of trees were inoculated with sterile MEA discs to serve as negative controls. Wounds were made in the bark at a constant height (about 400 to $800 \mathrm{~mm}$ above the ground) using a cork borer ( $9 \mathrm{~mm}$ in diameter). The inoculation trail was conducted in October 2008.

To evaluate the susceptibility of $S$. cumini to the Chrysoporthe cubensis isolates collected from South China, the same isolates as those used in field inoculations of Eucalyptus genotypes were inoculated onto the branches of $S$. cumini trees in ZhanJiang. For the five selected isolates, 10 branches from each of five $S$. cumini trees were inoculated per isolate. An equal number of branches were inoculated with sterile MEA discs to serve as negative controls. Inoculations were conducted in a similar way to those for the field and glasshouse inoculations, using a 9-mmdiameter cork borer. Branches were inoculated in September 2008, and the inoculation trial was repeated once, 7 days after the first inoculations on five different $S$. cumini trees.

Lesion lengths were recorded after 5 weeks for the Eucalyptus trees and 6 weeks for the $S$. cumini trees. To evaluate the pathogenicity of the isolates of $C$. cubensis to Eucalyptus genotypes and $S$. cumini, the lengths of the lesions in the cambium below the bark were recorded. Results from the experiments were analyzed separately in SAS (version 8) using the PROC GLM (28) and in a similar manner as for the greenhouse inoculation tests.

\section{RESULTS}

Sampling. Symptoms typical of infection by $C$. cubensis. were commonly observed on Eucalyptus and $S$. cumini trees in South China. These included dying branches, cracked bark, and cankers girdling the stems (Fig. 2A and B). Fruiting structures typical of $C$. cubensis, including ascostromata and conidiomata, were found on the surface of the cankers on Eucalyptus trees, whereas only ascostromata were observed on S. cumini. Isolates were obtained from a total of 25 Eucalyptus trees and 19 S. cumini trees. Of these, isolates were obtained from three E. camaldulensis and three E. urophylla $\times E$. grandis trees in HaiNan Province, four E. urophylla $\times E$. grandis trees in GuangXi Province, one each of three trees representing Eucalyptus clones W5, U6, and EC48, and one tree of an unknown Eucalyptus sp. in GuangDong 
Province (Table 1). Isolates were also collected from cankers on five Eucalyptus trees, including E. grandis, in GuangDong Province. All isolates of $C$. cubensis from S. cumini were collected from GuangDong Province (Fig. 1; Table 1).

Morphology. The ascostromata on the bark taken from cankers on Eucalyptus trees were semi-immersed, 120 to $200 \mu \mathrm{m}$ (average: $150 \mu \mathrm{m}$ ) high above the level of the bark, and 250 to $410 \mu \mathrm{m}$ (average: 350 $\mu \mathrm{m})$ wide above the surface of the bark
(Fig. 3A). The perithecial stromata were valsoid with perithecia partially embedded in the bark tissue. Perithecia were fuscous black in color and the tops of the perithecial bases were covered with cinnamon to orange fungal tissue, which was occasionally visible above the bark surface. The necks of the perithecia emerging from the stromata were covered with fuscous black tissue and were cylindrical, up to $520 \mu \mathrm{m}$ (average: $410 \mu \mathrm{m}$ ) in length and 100 to 150 $\mu \mathrm{m}$ (average: $120 \mu \mathrm{m}$ ) wide (Fig. 3A). Asci were $19.5-22$ to $26-27 \times 4.5-5$ to $6-6.5$ $\mu \mathrm{m}$, fusoid to ellipsoidal, containing eight ascospores. Ascospores were 5-5.5 to 7-8 $\times 2-3 \mu \mathrm{m}$, hyaline, 1-septate, fusoid to oval, with the ends tapering (Fig. 3F).

Stromatic conidiomata formed on the surfaces of the ascostromata or as separate structures, and were superficial to slightly immersed, pyriform to clavate (Fig. 3C). Stromatic conidiomatal bases were 130 to $430 \mu \mathrm{m}$ (average: $170 \mu \mathrm{m}$ ) high above the level of the bark and 190 to $750 \mu \mathrm{m}$ (aver-

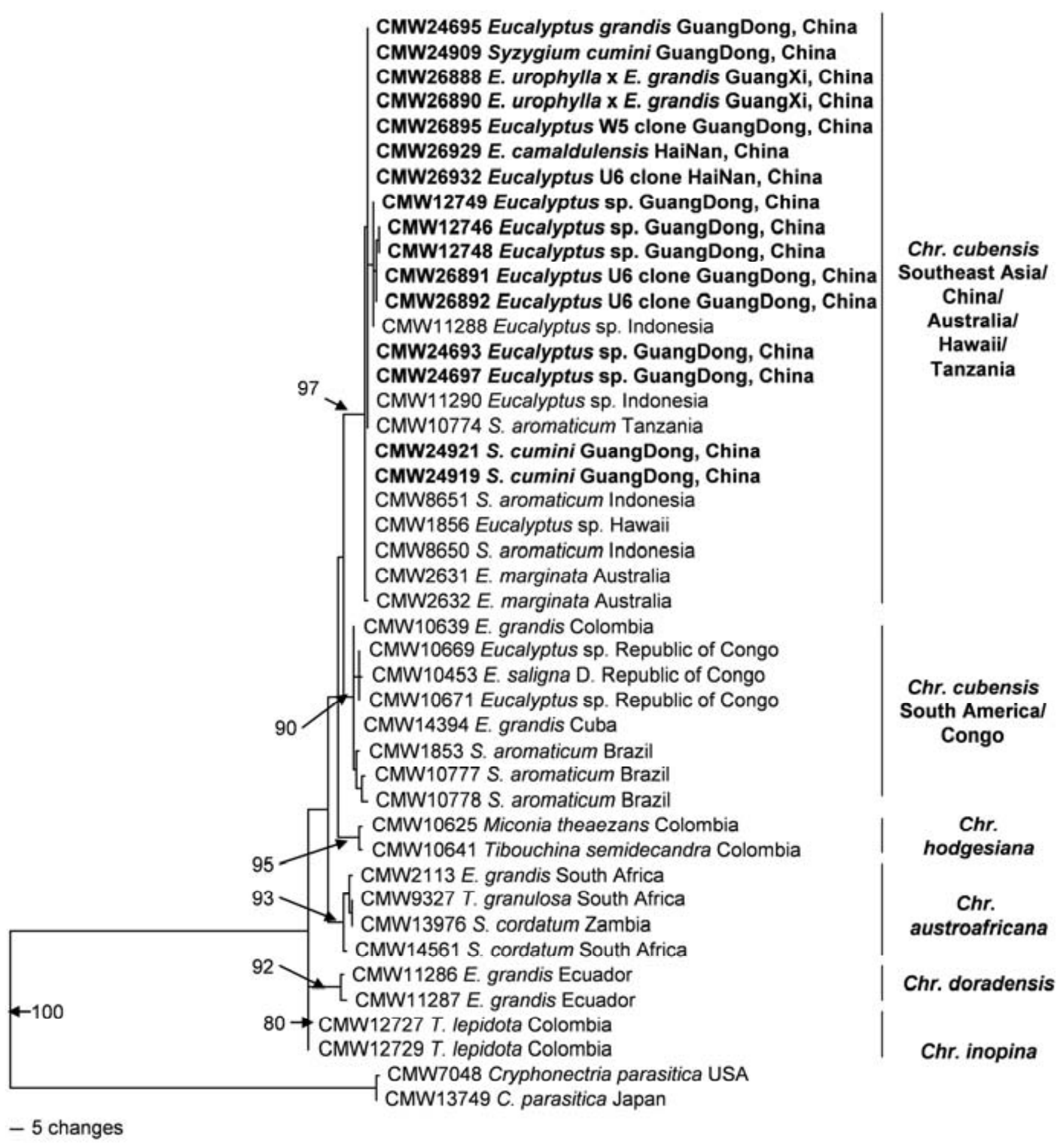

Fig. 4. One of 36 most parsimonious trees generated from combined sequence data of the internal transcribed spacer ribosomal DNA and $\beta$-tubulin gene sequence data and generated from heuristic searches performed on the combined data set (tree length of 348 , CI of 0.937 , and RI of 0.954 ). Bootstrap values (1,000 replicates) above $75 \%$ are indicated on the branches. Isolates sequenced in this study are in bold. Cryphonectria parasitica was used to root the tree. 
age: $320 \mu \mathrm{m}$ ) wide. Stromatic conidiomatal necks were up to $320 \mu \mathrm{m}$ long and 80 to $160 \mu \mathrm{m}$ wide (Fig. 3C). Stromatic conidiomatal locules with even to convoluted inner surface were occasionally multilocular, with single locules connected to one or several necks. Conidiophores were hyaline with globose to rectangular basal cells that were rounded off, $2.5-3$ to $6.5-9 \times 2-2.5$ to $4.5-6 \mu \mathrm{m}$, and branched irregularly at the base or above into cylindrical cells that were delimited by septa or not; conidiophores were $13-14.5$ to $21.5-26.5 \mu \mathrm{m}$ in length and conidiogenous cells were cylindrical to flask-shaped with attenuated apices, $1.5-2$ to $3-3.5 \mu \mathrm{m}$ wide (Fig. $3 \mathrm{G}$ ). Conidia were $3-3.5$ to $4.5-5 \times 1.5-2$ to 2.5-3 $\mu \mathrm{m}$, hyaline, oblong, aseptate, and exuded as bright luteous tendrils or droplets (Fig. 3H).

The morphology of ascostromata on $S$. cumini trees was similar to that on the Eucalyptus trees (Fig. 3B), and conidiomata were not observed. The emerging necks of the perithecia from stromata were

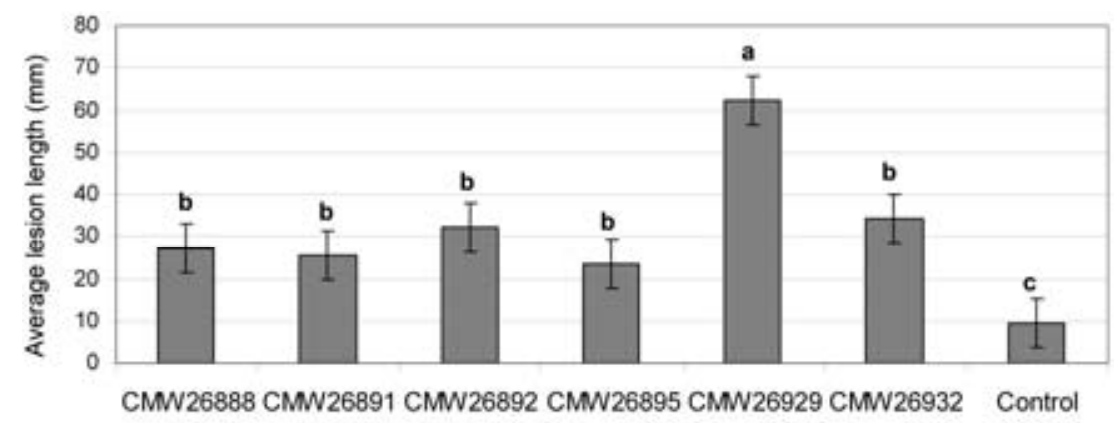

Treatments

Fig. 5. Column chart indicating the average lesion length (in millimeters) resulting from inoculation trials onto an Eucalyptus grandis clone (TAG-5) under glasshouse conditions. Six isolates of Chrysoporthe cubensis were used that was identified from Eucalyptus trees in China. Bars represent $95 \%$ confidence limits for each treatment. Different letters above the bars indicate treatments that were statistically significantly different $(P=0.05)$.

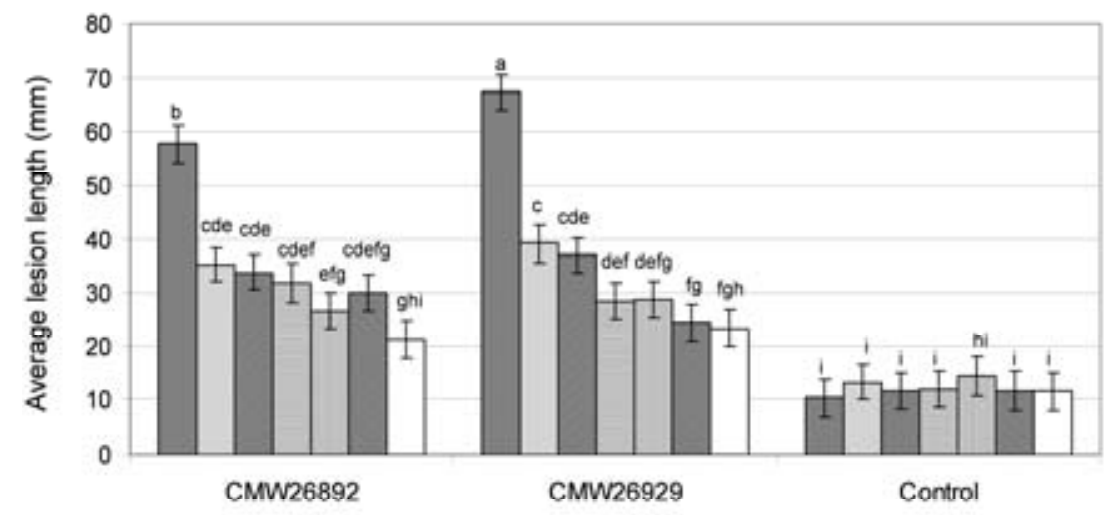

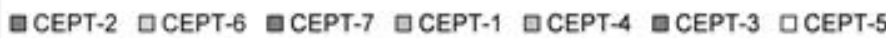

\section{Treatments}

Fig. 6. Column chart indicating the average lesion lengths (in millimeters) resulting from inoculation trials on seven Eucalyptus genotypes. Lesion lengths were produced by two Chrysoporthe cubensis isolates (CMW26892 and CMW26929). Bars represent 95\% confidence limits for each treatment. Different letters above the bars indicate treatments that were statistically significantly different $(P=0.05)$. on the results of previous studies $(9,11)$, they were combined in the phylogenetic analysis. The combined ITS and $\beta$-tubulin data set had 1,327 characters of equal weight, with 1,019 constant characters, of which 31 were parsimony uninformative and 277 were parsimony informative. In all, 36 most parsimonious trees were retained, and one of them $(50 \%$ majority rule), with tree length $=312$ steps, $\mathrm{CI}=$ $0.939, \mathrm{RI}=0.956, \mathrm{RC}=0.897$, and $\mathrm{HI}=$ 0.061 , was chosen to obtain a representative tree of the data (Fig. 4).

Results of the DNA sequence analyses showed that the isolates collected from Eucalyptus spp. in South China represented C. cubensis (Fig. 4). Isolates from the $S$. cumini trees were similar to those from Eucalyptus spp. Isolates from China grouped within the Asian clade of $C$. cubensis $(9,11,19)$ together with isolates originating from Australia, Hawaii, Indonesia, and Tanzania, with $97 \%$ bootstrap support, and separate from the South American clade of C. cubensis, with a $90 \%$ bootstrap (Fig. 4).

Differences were observed between isolates from China. Some of these isolates (CMW12746, CMW12748, CMW12749, CMW26891, and CMW26892) differed from the other isolates with two fixed nucleotide differences in the ITS gene region whereas, for the $\beta$-tubulin gene region, no differences were found between these isolates. The bootstrap values within the $C$. cubensis clade representing sequence differences are not significant (Fig. 4), suggesting that these reflect intraspecific sequence differences rather than interspecies variation.

Pathogenicity tests. Glasshouse trials. All C. cubensis isolates from China tested for pathogenicity on the Eucalyptus clone produced lesions within 6 weeks, while small lesions were produced for the control inoculations (Fig. 5). ANOVAs showed significant differences in susceptibility to the fungal isolates on the inoculated Eucalyptus clone $(P<0.001)$. The mean comparison tests showed that the lesion lengths produced by the $C$. cubensis isolates were significantly longer $(P<0.0001$ to $P=$ 0.0036) than those of the controls (Fig. 5). Of the isolates tested, lesions produced by isolate CMW26929 were significantly longer $(P<0.0001$ to $P=0.0004)$ than those of the other isolates (Fig. 5). All the inoculated fungi were successfully reisolated from the lesions, whereas no $C$. cubensis was isolated from the controls. Based on the glasshouse trial, isolates CMW26929 and CMW26892 were most virulent and, therefore, used for field inoculations.

Field trials in China. The two C. cubensis isolates (CMW26892 and CMW26929) inoculated on seven Eucalyptus genotypes gave rise to distinct lesions. ANOVAs showed significant differences in susceptibility to the fungal isolates between the 
various Eucalyptus genotypes $(P<0.001)$. Statistical analyses of the data showed that not all the isolates of $C$. cubensis reacted in the same manner to the tested Eucalyptus genotypes. For example, lesions produced by CMW26929 on Eucalyptus genotype CEPT-2 were significantly longer $(P=0.0437)$ than those of CMW26892 (Fig. 6) whereas, for the other Eucalyptus genotypes, the lesions produced by the two C. cubensis isolates were not significantly different $(P=0.2477$ to 0.6777$)$ (Fig. 6). The mean comparison tests further showed that the lesions produced by the two C. cubensis isolates (CMW26892 and CMW26929) from Eucalyptus were significantly longer $(P<0.0001$ to $P=$ 0.0477) than those of the controls, except for isolate CMW26892 $(P=0.053)$ on Eucalyptus CEPT-5 (Fig. 6). The results further showed that Eucalyptus genotype CEPT-2 is the most susceptible while genotype CEPT-5 is the most tolerant to infection by $C$. cubensis (Fig. 6).

Under field conditions, five C. cubensis isolates (CMW26892, CMW26929, CMW24909, CMW24919, and CMW24921) inoculated on two Eucalyptus genotypes (CEPT-6 and CEPT-7) also resulted in lesions. ANOVAs showed significant differences in susceptibility to the fungal isolates between the two Eucalyptus genotypes $(P<0.001)$. The three $C$. cubensis isolates (CMW24909, CMW24919, and CMW24921) originating from S. cumini trees produced lesions on both Eucalyptus genotypes (CEPT-6 and CEPT-7). The mean comparison tests showed that lesions produced by two of the isolates (CMW24909 and CMW24919) were significantly longer $(P<0.0001$ to $P=0.0085)$ than those produced by the controls (Fig. 7). However, lesions produced by isolates (CMW26892 and CMW26929) originating from Eucalyptus trees were significantly longer $(P<$ $0.0001)$ than those produced by the two isolates (CMW24919 and CMW24921) from S. cumini trees (Fig. 7).

Where S. cumini branches were inoculated with $C$. cubensis isolates from Eucalyptus spp. (CMW26892 and CMW26929) and S. cumini (CMW24909, CMW24919, and CMW24921), distinct lesions developed after 6 weeks. For the first inoculation experiment, ANOVAs showed significant differences in susceptibility to the fungal isolates on the inoculated $S$. cumini branches $(P=0.0516)$. Statistical analyses of the data showed that not all the isolates of $C$. cubensis reacted in the same manner to all the tested $S$. cumini branches. For example, lesions produced by CMW26929 were significantly longer than those of CMW26892 $(P=0.0269)$ and CMW24909 $(P=0.0058)$ (Fig. 8). In the second test, ANOVAs showed no significant differences in susceptibility to the fungal isolates on the inoculated $S$. cumini branches $(P=0.9730)$. For each experiment, all five isolates produced significantly longer le- sions $(P<0.0001)$ than those of the controls (Fig. 8).

\section{DISCUSSION}

Results of the present study confirmed the presence of $C$. cubensis on Eucalyptus spp. in mainland China. The fungus had previously been reported only from Hong Kong, China $(12,14,21,30)$. This is especially important because recent studies (12) have shown that there are various closely related species of Chrysoporthe that can be confused with each other and that multigene DNA sequence analysis is needed to obtain unequivocal identifications. As part of this study, the new host $S$. cumini is recorded for $C$. cubensis. Inoculation trials confirmed the pathogenicity of C. cubensis on the Eucalyptus genotypes used for plantation forestry in China as well as on S. cumini. Genotypes of Eucalyptus were shown to differ in their susceptibility to this pathogen.

Comparisons of sequence data for the ITS and $\beta$-tubulin gene regions provided definitive evidence that isolates of Chrysoporthe collected from China were those of $C$. cubensis. Previous research has shown that, based on ITS, $\beta$-tubulin, and Histone $\mathrm{H} 3$ gene sequence data, $C$. cubensis isolates reside in two very distinct phylogenetic clades. These clades represent isolates from Southeast Asia and South America $(9,11,19)$. Based on sequence data for ITS and $\beta$-tubulin gene regions, isolates from South China group within the Southeast Asian clade of this species.

Field inoculation studies using different Eucalyptus genotypes grown in South China provided valuable data for the selection of future planting material in the country. The susceptibility of the genotypes tested differed significantly from each other. This is similar to results of screening trials in South Africa $(5,34,35)$, which have resulted in the effective management of canker caused by $C$. austroafricana through the identification of disease-resistant planting stock $(35,36,38)$. Thus, in South Africa, it is currently difficult to find $C$. austroafricana infections on Eucalyptus trees in plantations due to the success of selection and breeding programs that have been supported by disease

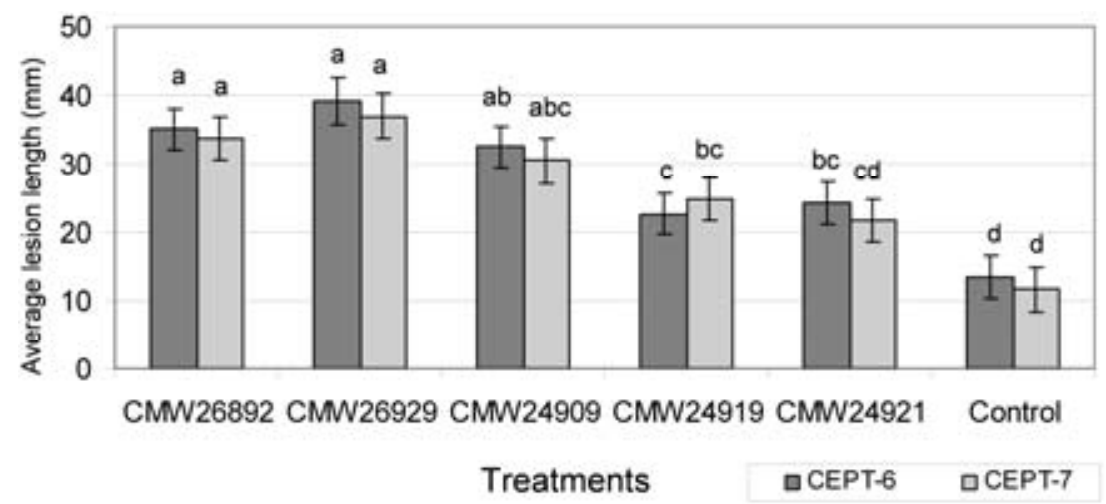

Fig. 7. Column chart indicating the average lesion lengths (in millimeters) resulting from inoculation trials on two Eucalyptus genotypes (CEPT-6 and CEPT-7) in the field. Five Chrysoporthe cubensis isolates were used, with two isolates (CMW26892 and CMW26929) identified from Eucalyptus trees and three isolates (CMW24909, CMW24919, and CMW24921) identified from Syzygium cumini trees. Bars represent $95 \%$ confidence limits for each treatment. Different letters above the bars indicate treatments that were statistically significantly different $(P=0.05)$.

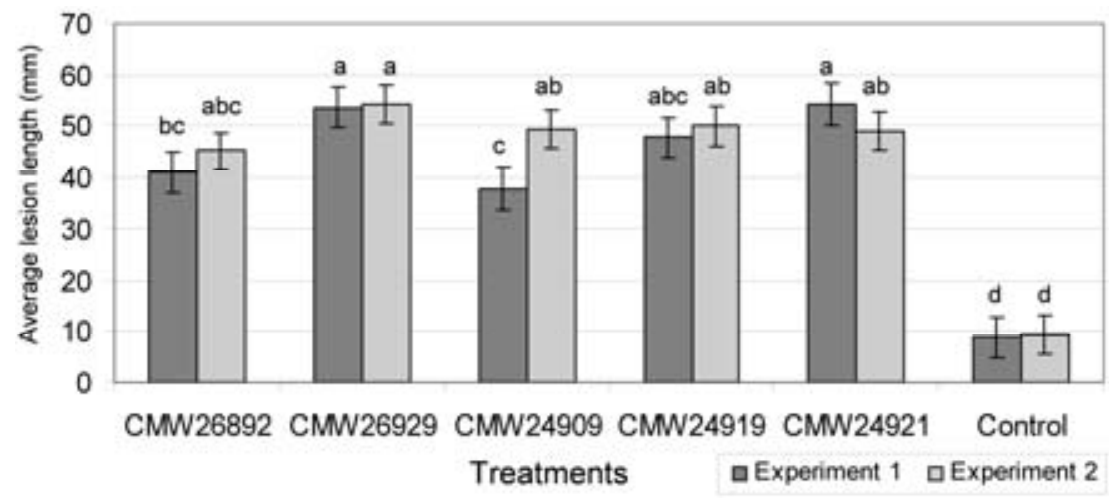

Fig. 8. Column chart indicating the average lesion lengths (in millimeters) resulting from inoculation trials on branches of Syzygium cumini that were inoculated with five Chrysoporthe cubensis isolates. Two of these isolates (CMW26892 and CMW26929) were identified from Eucalyptus trees and three isolates (CMW24909, CMW24919, and CMW24921) were identified from S. cumini trees. Bars represent $95 \%$ confidence limits for each treatment. Different letters above the bars indicate treatments that were statistically significantly different $(P=0.05)$. 
screening via inoculation (J. Roux, unpublished data). As a further aid to the selection of disease-tolerant planting material, genetic markers have been developed in South Africa to aid in effective screening of species, hybrids, and clones (17). This is an approach that might be useful in China.

An interesting outcome of this study was the discovery of $C$. cubensis on $S$. cumini. This tree is planted as an ornamental in South China and is native to the nearby countries of Bangladesh, India, Indonesia, Nepal, and Pakistan. In this regard, it seems likely that it is also a natural host of the pathogen in Southeast Asia. This would be consistent with the fact that $C$. cubensis has been found on other native members of the order Myrtales in Southeast Asia and in South and Central America and has apparently undergone a host shift (31) to infect Eucalyptus spp. $(11,22,27)$. Similarly, the closely related pathogen $C$. austroafricana is found on native Syzygium spp. in South Africa and it has apparently undergone a host shift to infect Eucalyptus spp. (13,22). Pathogenicity tests in this study also showed that $S$. cumini is susceptible to infection by C. cubensis. This could explain the extensive cankering and branch die-back observed regularly on $S$. cumini trees.

This study represents the first comprehensive work that investigates the pathogenicity of C. cubensis on Eucalyptus and $S$. cumini trees in China. Moreover, the identification of commercially available Eucalyptus genotypes tolerant to Chrysoporthe canker will promote the selection of tolerant stocks for wide-scale planting. This approach has been shown to effectively reduce the disease severity in other parts of the world $(15,35,36)$ and it should also be useful in China.

\section{ACKNOWLEDGMENTS}

This study was initiated through the bilateral agreement between South Africa and China, and funded through projects 30771732 and 2007DFA31190. We thank the members of the Tree Protection Cooperative Programme (TPCP) for financial and logistical support; T. Burgess (Murdoch University, Australia) for providing some isolates used in this study; H. Groeneveld and M. van der Linde for assistance with the statistical analyses, and colleagues at the LeiZhou Forestry Bureau (X.-T. Mou, G.-X. Zhao, and C.-Y. Xie) for their valuable assistance in the field.

\section{LITERATURE CITED}

1. Alfenas, A. C., Jeng, R., and Hubbes, M. 1983. Virulence of Cryphonectria cubensis on Eucalyptus species differing in resistance. Eur. J. For. Pathol. 13:197-205.

2. Campinhos, E., and Ikemori, Y. K. 1983. Mass production of Eucalyptus spp. by rooting cuttings. Silvicultura 8:770-775.

3. Chungu, D., Gryzenhout, M., MuimbaKankolongo, A., Wingfield, M. J., and Roux, J. 2010. Taxonomy and pathogenicity of two novel Chrysoporthe species from Eucalyptus grandis and Syzygium guineense in Zambia. Mycol. Pro. DIO 10.1007/s11557-009-0646-9.

4. Conradie, E., Swart, W. J., and Wingfield, M. J. 1990. Cryphonectria canker of Eucalyptus, an important disease in plantation forestry in South Africa. S. Afr. For. J. 152:43-49.
5. Conradie, E., Swart, W. J., and Wingfield, M. J. 1992. Susceptibility of Eucalyptus grandis to Cryphonectria cubensis. Eur. J. For. Pathol. 22:312-315.

6. Farris, J. S., Källersjö, M., Kluge, A. G., and Bult, C. 1994. Testing significance of incongruence. Cladistics 10:315-319.

7. Felsenstein, J. 1985. Confidence intervals on phylogenetics: an approach using bootstrap. Evolution 39:783-791.

8. Glass, N. L., and Donaldson, G. C. 1995. Development of primersets designed for use with the PCR to amplify conserved genes from filamentous ascomycetes. Appl. Environ. Microbiol. 61:1323-1330.

9. Gryzenhout, M., Myburg, H., Van der Merwe, N. A., Wingfield, B. D., and Wingfield, M. J. 2004. Chrysoporthe, a new genus to accommodate Cryphonectria cubensis. Stud. Mycol. 50:119-142.

10. Gryzenhout, M., Myburg, H., Wingfield, B. D., Montenegro, F., and Wingfield, M. J. 2005. Chrysoporthe doradensis sp. nov. pathogenic to Eucalyptus in Ecuador. Fungal Divers. 20:39-57.

11. Gryzenhout, M., Rodas, C. A., Portales, J. M., Clegg, P., Wingfield, B. D., and Wingfield, M. J. 2006. Novel hosts of the Eucalyptus canker pathogen Chrysoporthe cubensis and a new Chrysoporthe species from Colombia. Mycol. Res. 110:833-845.

12. Gryzenhout, M., Wingfield, B. D., and Wingfield, M. J. 2009. Taxonomy, Phylogeny, and Ecology of Bark-Inhabiting and Tree Pathogenic Fungi in the Cryphonectriaceae. American Phytopathological Society, St. Paul, MN.

13. Heath, R., Gryzenhout, M., Roux, J., and Wingfield, M. J. 2006. Discovery of the canker pathogen Chrysoporthe austroafricana on native Syzygium spp. in South Africa. Plant Dis. 90:433-438.

14. Hodges, C. S., Alfenas, A. C., and Ferreira, F. A. 1986. The conspecificity of Cryphonectria cubensis and Endothia eugeniae. Mycologia 78:343-350.

15. Hodges, C. S., Reis, M. S., Ferreira, F. A., and Henfling, J. D. M. 1976. O cancro do eucalipto causado por Diaporthe cubensis. Fitopatal. Bras. 1:129-167.

16. Katoh, K., Misawa, K., Kuma, K., and Miyata, T. 2002. MAFFT: A novel method for rapid multiple sequence alignment based on fast Fourier transform. Nucleic Acids Res. 30:30593066.

17. Lezar, S., Myburg, A. A., Berger, D. K., Wingfield, M. J., and Wingfield, B. D. 2004. Development and assessment of microarray-based DNA fingerprinting in Eucalyptus grandis. Theor. Appl. Genet. 109:1329-1336.

18. Myburg, H., Gryzenhout, M., Heath, R., Roux, J., Wingfield, B. D., and Wingfield, M. J. 2002. Cryphonectria canker on Tibouchina in South Africa. Mycol. Res. 106:1299-1306.

19. Myburg, H., Gryzenhout, M., Wingfield, B. D., and Wingfield, M. J. 2002. $\beta$-Tubulin and Histone $H 3$ gene sequences distinguish Cryphonectria cubensis from South Africa, Asia, and South America. Can. J. Bot. 80:590-596.

20. Myburg, H., Gryzenhout, M., Wingfield, B. D., and Wingfield, M. J. 2003. Conspecificity of Endothia eugeniae and Cryphonectria cubensis: A re-evaluation based on morphology and DNA sequence data. Mycoscience 44:187-196.

21. Myburg, H., Wingfield, B. D., and Wingfield, M. J. 1999. Phylogeny of Cryphonectria cubensis and allied species inferred from DNA analysis. Mycologia 91:243-250.

22. Nakabonge, G., Roux, J., Gryzenhout, M., and Wingfield, M. J. 2006. Distribution of Chrysoporthe canker pathogens on Eucalyptus and Syzygium species in eastern and southern Africa. Plant Dis. 90:734-740.

23. Nutman, F. J., and Roberts, F. M. 1952. Acute die-back of clove trees in the Zanzibar Protectorate. Ann. Appl. Biol. 39:599-607.

24. Old, K. M., Wingfield, M. J., and Yuan, Z. Q. 2003. A Manual of Diseases of Eucalypts in South-East Asia. Centre for International Forestry Research, Jakarta, Indonesia.

25. Reid, J., and Booth, C. 1969. Some species segregated from the genera Cryptospora Cryptosporella, and Sillia. Can. J. Bot 47:1055-1060.

26. Rodas, C. A., Gryzenhout, M., Myburg, H., Wingfield, B. D., and Wingfield, M. J. 2005. Discovery of the Eucalyptus canker pathogen Chrysoporthe cubensis on native Miconia (Melastomataceae) in Colombia. Plant Pathol. 54:460-470.

27. Roux, J., Myburg, H., Wingfield, B. D., and Wingfield, M. J. 2003. Biological and phylogenetic analyses suggest that two Cry phonectria species cause cankers of Eucalyptus in Africa. Plant Dis. 87:1329-1332.

28. SAS Institute Inc. 1999. SAS/STAT Users Guide, Version 8. SAS Institute Inc., Cary, NC.

29. Seixas, C. D. S, Barreto, R. W., Alfenas, A. C. and Ferreira, F. A. 2004. Cryphonectria cubensis on an indigenous host in Brazil: a possible origin for eucalyptus canker disease? Mycologist 18:39-45.

30. Sharma, J. K., Mohanan, C., and Florence, E. J. M. 1985. Occurrence of Cryphonectria canker disease of Eucalyptus in Kerala, India. Ann. Appl. Biol. 106:265-276.

31. Slippers, B., Stenlid, J., and Wingfield, M. J. 2005. Emerging pathogens: fungal host jumps following anthropogenic introduction. Trends Ecol. Evol. 20:420-421.

32. Swofford, D. L. 2002. PAUP*. Phylogenetic Analysis Using Parsimony (*and other methods), Version 4. Sinauer Associates, Sunderland, MA

33. Tamura, K., Dudley, J., Nei, M., and Kumar, S. 2007. MEGA4: Molecular Evolutionary Genetics Analysis (MEGA) software version 4.0 Mol. Biol. Evol. 24:1596-1599.

34. Van der Westhuizen, I. P., Wingfield, M. J., Kemp, G. H. J., and Swart, W. J. 1992. Comparative susceptibility of Eucalyptus grandis clones and hybrids to Cryphonectria cubensis. (Abstr.) Phytophylactica 24:107.

35. Van Heerden, S. W., Amerson, H. V., Preisig, O. Wingfield, B. D., and Wingfield, M. J. 2005 Relative pathogenicity of Cryphonectria cubensis on Eucalyptus clones differing in the tolerance to C. cubensis. Plant Dis. 89:659-662.

36. Van Heerden, S. W., and Wingfield, M. J. 2002. Effect of environment on the response of Eucalyptus clones to inoculation with Cryphonectria cubensis. For. Pathol. 32:395-402.

37. White, T. J., Bruns. T., Lee. S., and Taylor, J. 1990. Amplification and direct sequencing of fungal ribosomal RNA genes for phylogenetics. Pages 315-322 in: PCR Protocols: A Guide to Methods and Applications. M. A. Innis, D. H. Gelfand, J. J. Sninsky, and T. J. White, eds. Academic Press, San Diego, CA.

38. Wingfield, M. J. 2003. Increasing threat of diseases to exotic plantation forests in the southern hemisphere: lessons from Cryphonectria canker. Australas. Plant Pathol. 32:133-139.

39. Wingfield, M. J., Rodas, C., Wright, J., Myburg, H., Venter, M., and Wingfield, B. D. 2001. First report of Cryphonectria canker on Tibouchina in Colombia. For. Pathol. 31:297-306.

40. Wingfield, M. J., Swart, W. J., and Abear, B. 1989. First record of Cryphonectria canker of Eucalyptus in South Africa. Phytophylactica 21:311-313.

41. Xie, Y. J. 2006. Eucalypt research at the beginning of 21st century. China Forestry House Press, Beijing. (In Chinese)

42. Zhou, X. D., Xie, Y. J., Chen, S. F., and Wingfield, M. J. 2008. Diseases of eucalypt plantations in China: challenges and opportunities. Fungal Divers. 32:1-7. 